\title{
ILCEA
}

Revue de l'Institut des langues et cultures

d'Europe, Amérique, Afrique, Asie et Australie

$40 \mid 2020$

English for Specific Purposes (ESP) and the Underlying Dynamics of Power, Empowerment and Disempowerment

\section{Dictionaries of Science and Technology and Issues of Power}

Dictionnaires des sciences et des technologies et questions de pouvoir

\section{Olga Menagarishvili}

\section{(2) OpenEdition \\ Journals}

Electronic version

URL: http://journals.openedition.org/ilcea/10614

DOI: 10.4000/ilcea.10614

ISSN: 2101-0609

\section{Publisher}

UGA Éditions/Université Grenoble Alpes

Printed version

ISBN: 978-2-37747-204-8

ISSN: 1639-6073

\section{Electronic reference}

Olga Menagarishvili, "Dictionaries of Science and Technology and Issues of Power », ILCEA [Online]

40 | 2020, Online since 04 June 2020, connection on 05 September 2020. URL : http://

journals.openedition.org/ilcea/10614 ; DOI : https://doi.org/10.4000/ilcea.10614

\section{This text was automatically generated on 5 September 2020}

(c) ILCEA 


\title{
Dictionaries of Science and Technology and Issues of Power
}

Dictionnaires des sciences et des technologies et questions de pouvoir

\author{
Olga Menagarishvili
}

\section{Introduction}

Dictionaries of science and technology define scientific and technical terms for a variety of audiences and are a genre widely used in communicating on scientific and technical topics. Dictionaries in general, and dictionaries of science and technology in particular, are key objects of study since they exercise power by assigning value to knowledge. For centuries, the knowledge found in dictionaries has been considered to be more authoritative and "valuable" than the knowledge not referenced by these works. In this way, dictionaries have been dictating what knowledge may be considered as valuable and trustworthy. Moreover, because dictionaries are often viewed as mundane documents, their power is invisible, which makes them even stronger.

2 The ability to transform knowledge into value has been identified as one of the most important social functions of scientific and technical communication (Longo, 2000: $\mathrm{xI}$ ). As such, it is important to make visible the hidden mechanisms of this process of transformation. Given that the question has not been explored much by researchers, it is enlightening to explore dictionaries of science and technology as artifacts of scientific and technical communication that play an important role in creating and stabilizing scientific and technical knowledge.

The main purpose of this article is to propose a model that may be used to throw light on some of the hidden mechanisms behind the power of dictionaries of science and technology. To illustrate the use of the model, one of the most recent and authoritative dictionaries of science and technology published in English, McGraw-Hill Dictionary of Scientific and Technical Terms, is analyzed. The methods include cultural analysis, lexicographic archaeology, and employing a production-consumption model. 


\section{Theory: Power of Dictionaries}

Dictionaries possess several types of power. First of all, they have the ability to influence knowledge legitimation as powerful tools for education. Their connection with education is obvious from the very first glossaries created by monks for selfeducation (Jackson, 2002: 31; Landau, 1984: 37), the "hard word" dictionaries that were supposed to help women and children learn "difficult" words (Béjoint, 1994: 94), the dictionaries of the seventeenth and the eighteenth centuries created in the Academies (Landau, 1984: 48) and finally, to modern learner's dictionaries (Jackson, 2002: 129). In this sense, dictionaries are very similar to textbooks, in that dictionaries of science and technology, for example, are often used to train technical translators or students exploring a new subject field.

Dictionaries also participate in knowledge legitimation as tools for creating what Anderson calls "imagined communities" that can be defined as communities consisting of people who "will never know most of their fellow-members, meet them, or even hear of them, yet in the minds of each lives the image of their communion" (2006: 6). Such communities are present in our lives even though most of the time, we are unaware of them, a form of invisibility that makes such imagined communities even more powerful. Dictionaries participate in creating imagined communities and in knowledge legitimation in these communities in two ways.

6 On the one hand, dictionaries are always closely connected with language, which is often used as a basis for creating imagined communities of those who speak this language. For example, Anderson points out that "the lexicographic revolution" that took place in the nineteenth century in Europe, "created, and gradually spread, the conviction that languages (in Europe at least) were, so to speak, the personal property of quite specific groups-their daily speakers and readers-and moreover that these groups, imagined as communities, were entitled to their autonomous place in a fraternity of equals" (2006: 84). Kernan (1987:185) explores the close connection between a dictionary and the language it describes and argues that for some people, a dictionary often becomes the language. Béjoint calls dictionaries "patriotic emblems" and writes that dictionaries are "the rare objects that can materialize the existence of a language, and hence of a nation, acting as a symbol of the unification of a community" (1994: 138). Indeed, if other books are written in certain languages as well and thus create certain imagined communities of those who could read them, dictionaries, on the other hand, are not only written in a particular language, but also describe this language. And since language often creates imagined communities, it is obvious that dictionaries play a powerful role in this area.

Dictionaries of science and technology also create imagined communities in this sense. Since they focus on languages for special purposes, the imagined communities they create are naturally smaller than the ones created by general dictionaries. Nevertheless, the role they play in describing those parts of language that are used to communicate about science and technology cannot be denied.

Dictionaries are powerful in forming imagined communities through standardization, signaling that members of such or such group use (descriptive) or should use (prescriptive) the language the way it is defined in the dictionary. In spite of the fact that the descriptive approach that focuses on how the language is used, as opposed to 
how it should be used, remains the guiding principle for the majority of dictionary makers, most dictionaries are still perceived as prescriptive and, thus, as normative texts which dictate the rules of language use for certain imagined communities. A common belief, for example, is that if a certain meaning is not in the sacrosanct OED, it does not exist in English (Harris, 1982: 936).

Standardization performed by dictionaries of science and technology has been widely discussed in the literature. Overall, standardization is seen by many researchers to be a necessary attribute of dictionaries of science and technology on two levels: the macrolevel, i.e. the structure of the dictionary (Cubillo, 2002: 216), and the micro-level, i.e. the structure of the dictionary articles, including the definitions, of course (Cubillo, 2002: 216; Faber, Araús, Prieto Velasco \& Reimerink, 2006: 45; Frawley, 1988: 193; Pedersen, 1995: 61). However, very few studies (Layton, 1965; Norman, 2002; Yeo, 2001) discuss the power or the social function of standardization when it comes to dictionaries of science and technology.

Since dictionaries possess power, it is important to analyze who the main power players, i.e. dictionary compilers, are. Though no studies have been found that focus on the role of dictionary compilers with regard to dictionaries of science and technology, one of the issues that has been discussed in the studies of dictionaries of science and technology is the cooperation between specialists in the subject field and lexicographers (professional dictionary-makers), namely, the level of involvement of the former group in the creation of a dictionary (Frawley, 1988: 196; Opitz, 1983: 167; Pedersen, 1995: 68-9).

11 As can be seen from the discussion above, dictionaries in general and dictionaries of science and technology in particular possess power as symbols of education and tools for creating imagined communities. However, considering dictionaries of science and technology just from these two perspectives would be insufficient. This study attempts to contribute to this discussion first by proposing a model that could be used to bring to light some of the mechanisms behind the power of dictionaries of science and technology and then, to illustrate the use of the model, by analyzing one of the most recent and authoritative dictionaries of science and technology published in English, McGraw-Hill Dictionary of Scientific and Technical Terms.

\section{Methodological Framework and Methodology}

\subsection{Methodological Framework}

12 One of the ways to discuss power issues connected with dictionaries of science and technology is to consider these reference works as participants in the scientific knowledge economy, namely, as participants in knowledge making and as products of capitalism.

\subsubsection{Dictionaries of Science and Technology as Participants in Knowledge Making}

13 The theoretical framework for considering dictionaries of science and technology as participants in knowledge making focuses essentially on Longo's work connecting 
scientific and technical communication and the scientific knowledge economy, Latour's model of knowledge accumulation, and Leitch's notion of institutions.

One of the guiding lines used in the study is the connection between scientific and technical communication and the scientific knowledge economy. This connection has been established by Longo, who discusses the relations between technical writing, technical knowledge, and economic security and emphasizes that technical writing assigns value to knowledge and that "the stamp of science gave technical language its economic value, just as the stamp of the King gave coinage its representational value as currency" (2000: XIII).

The second principle used in this study concerns Latour's model of knowledge accumulation:

[...] what is called 'knowledge' cannot be defined without understanding what gaining knowledge means. In other words, 'knowledge' is not something that could be described by itself or by opposition to 'ignorance' or to 'belief', but only by considering a whole cycle of accumulation: how to bring things back to a place for someone to see it for the first time so that others might be sent again to bring other things back. How to be familiar with things, people and events, which are distant. (1987: 220)

Latour introduces a model of knowledge accumulation (see Figure 1) to illustrate how knowledge is accumulated when new territories are explored.

Figure 1. - Latour's model of knowledge accumulation (1987: 220-1).

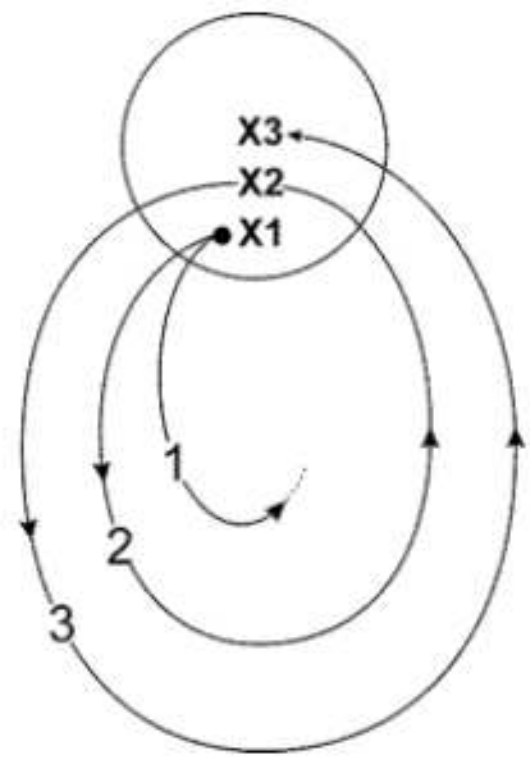

Latour explains his model as follows:

Expedition number one disappears without trace, so there is no difference in 'knowledge' between the first and the second that fumbles its way in darkness always at the mercy of each of the people whose path is crossed. More fortunate than the first, this second expedition not only comes back but brings something (noted X2 in the drawing) that allows the third to be so familiar with the coastline that they can quickly move to other lands bringing home parts of a map of a new territory (X3). At every run of this accumulation cycle, more elements are gathered in the center (represented by a circle at the top); at every run the asymmetry (at the bottom) between the foreigners and the natives grows. (1987: 220-1) 

creating maps of gaining knowledge. However, his model can be extended to the process of compiling new dictionary editions. If the material for the first dictionary edition has been collected, but that dictionary edition does not get published, "there is no difference in 'knowledge' between the first and the second" editions (Latour, 1987: 220). Further, the dictionary compiler collects the material for the second dictionary edition and publishes it (X2 in the drawing), which allows the compiler of the third dictionary edition to be familiar with the published material and to "bring home" and add new information (X3). The creation of every new dictionary edition becomes the "run of this accumulation cycle" (Latour, 1987: 221), so in every dictionary edition, "more elements are gathered in the center" (ibid.).

Latour's model of knowledge accumulation is a promising model for this study because it allows us to examine how dictionaries contribute to knowledge making. His model illustrates the accumulative nature of knowledge as it describes a whole cycle of knowledge accumulation that helps "bring things back to a place for someone to see it for the first time so that others might be sent again to bring other things back" and "to be familiar with things, people and events, which are distant" (1987: 220). Similarly, when a new edition of a dictionary is created, some new information is gathered at a distance and then brought to the center so that dictionary users may "see it for the first time" (ibid.), and a group of lexicographers might begin a new cycle of knowledge accumulation in order to bring new information to the center and create a new dictionary edition. Latour's model gives a sound basis for the description of how knowledge is created with the help of dictionaries.

Another notion that is used in this study is the role of institutions. Leitch provides examples of institutions and other phenomena (academic publishing companies, bookstores and libraries, as well as literary history, classroom pedagogy, and normative critical practice) and points out that "through various discursive and technical means, institutions constitute and disseminate systems of rules, conventions, and practices that condition the creation, circulation, and use of resources, information, knowledge, and belief" (1992: 128). In a study that focused on dictionaries of science and technology as participants in knowledge making, it appears important to consider the role of institutions such as publishing companies in this process.

Longo's idea about the connection between scientific and technical communication and the scientific knowledge economy, Latour's model of knowledge accumulation, and Leitch's notion of institutions are helpful in analyzing dictionaries of science and technology as participants in the scientific knowledge economy.

\subsubsection{Dictionaries of Science and Technology as Products of Capitalism}

In addition to being participants in the knowledge-making process, dictionaries in general, and dictionaries of science and technology in particular, are also products of capitalism.

Books became one of the most important products of capitalism with the invention of print (Anderson, 2006:39). As Anderson points out, "one of the earlier forms of capitalist enterprise, book-publishing felt all of capitalism's restless search for markets" (2006: 39). Contemporary lexicographers agree that dictionaries are made to be sold. Landau, for example, defines the act of compiling a dictionary as "the attempt 
to fashion a custom-made product on an assembly-line basis" (2001:343). Because dictionaries are products of capitalism and are made to be sold, Latour's model of knowledge accumulation may be expanded by adding consumption cycles to the knowledge accumulation or production cycles (see Figure 2).

Figure 2. - The model of production-consumption cycles.

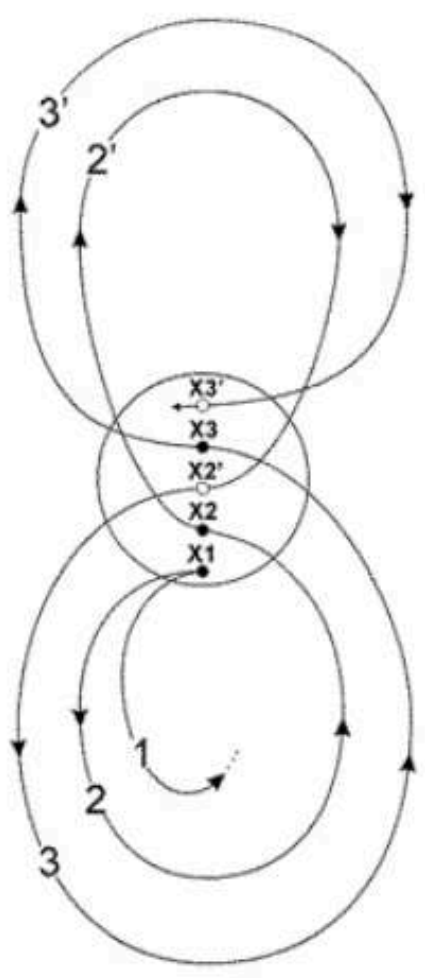

As we can see in the figure, production cycle 1 is incomplete if the material for the first dictionary version has been collected, but the dictionary version does not get published. After the dictionary compiler collects the material for a dictionary version and publishes it ( $\mathrm{X} 2$ in the drawing; production cycle 2 is completed), this dictionary version is sold and used by the public (consumption cycle 2' is completed). Going through the consumption cycle might provide additional information that could potentially lead to a new dictionary version (X2'). However, at this point, this dictionary version is not realized. Production cycle 3 begins when the compiler of the third dictionary version "brings [it] home" and adds new information to the second dictionary version, which leads to the third version (X3), thus completing production cycle 3. The third version is then sold and used by the public (consumption cycle 3'), etc. As such, the creation of each dictionary version becomes the production cycle, while selling and using this version corresponds to the consumption cycle.

\subsection{Methodology}

McGraw-Hill Dictionary of Scientific and Technical Terms was chosen for this analysis because it is one of the most popular dictionaries of science and technology and has gone through at least six editions. For the purposes of this study, the 1974, 1978, 1984, 1989, 1994, and 2003 editions were analyzed. 

us to examine how each dictionary edition functions in the production-consumption cycles (see Figure 2). We used the results of the cultural analysis and the results of the lexicographic archaeological analysis to create models of production-consumption cycles.

\section{Results}

\subsection{Edition 1: 1974}

Figure 3 is a production-consumption model of the first edition of the McGraw-Hill Dictionary of Scientific and Technical Terms. The circle in the middle represents the "center", which includes the institution that published the dictionary and, therefore, "disseminate[s] systems of rules, conventions, and practices that condition the creation, circulation, and use of resources, information, knowledge, and belief" (Leitch, 1992: 128). McGraw-Hill Book Company is the institution for all 6 editions of the dictionary. 
Figure 3. - Production-consumption model of the first edition of McGraw-Hill Dictionary of Scientific and Technical Terms.

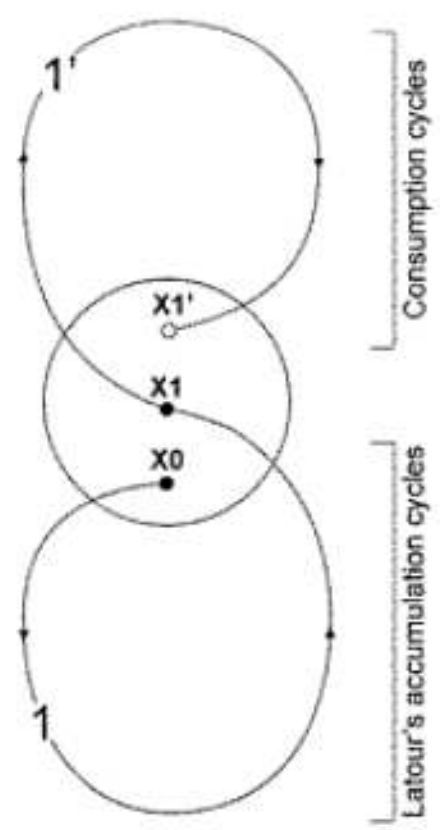

Several groups of people working for McGraw-Hill Book Company were involved in creating the first edition of the dictionary. These groups play an important role because they possess the decisional power of how the language of science and technology is described. In the case of this edition, the editorial staff was composed of an Editor in Chief, a Senior Editor, an Editor, two Art Directors, an Art Coordinator, an Editing Manager, a Copy Editor, and two Editing Assistants. Contributing editors, consulting editors, and library consultants were also involved in creating the content of the dictionary, but were not considered "editorial staff". According to the Introduction to the dictionary, it is the contributing editors who wrote the definitions. The role of the consulting editors was to select the terms to be included and decide which definitions were most suitable. Library consultants also contributed in helping to review definitions. In all, seven contributing editors and 27 consulting editors and library consultants worked on this edition. Their titles, positions, organizations, and the field(s) they were responsible for are duly listed to establish their authority.

Once the compilers had collected the material for the dictionary, the first edition was published (X1 in the figure; production cycle 1 was completed). During this cycle, all the information necessary for creating the word list of the dictionary was collected and brought to the center. At the same time, during production cycle 1 , the dictionary compilers were getting ready for consumption cycle 1', during which the first edition of the dictionary would be sold. In order to make sure the dictionary was commercially successful, several key topics were discussed in the front matter of the dictionary. These topics included the rapid growth of science and technology in the years that preceded the publication of the dictionary, the use of the latest technologies in making the dictionary, and some of the characteristics that make the dictionary stand out, namely, comprehensiveness, a balanced style of definitions, and affordability. The focus was on the development of science and technology rather than on creating a "complete" corpus of knowledge. 

completed). During this cycle, some additional information that could potentially lead to a new dictionary edition (X1') may have been collected. However, at this point, this edition was not realized.

\subsection{Edition 2: 1978}

The same publisher remains in the center even though several changes were made to the list of the dictionary compilers. Four new people were added to the editorial staff (see Table 1). Also, two new people were added to the list of contributing editors and six to the list of consulting editors and library consultants. As was the case for first edition, the contributors' titles, positions, organizations, and the field(s) they were responsible for were detailed in order to establish their authority.

Table 1. - Changes in the Editorial Staff of McGraw-Hill Dictionary of Scientific and Technical Terms.

\begin{tabular}{|c|c|c|}
\hline Edition & New Compilers & Compilers from Previous Edition \\
\hline 2 & $\begin{array}{l}\text { Senior Editing Assistant } \\
\text { Two Editing Assistants } \\
\text { Person responsible for "Art/Traffic" }\end{array}$ & $\begin{array}{l}\text { Editor in Chief } \\
\text { Senior Editor } \\
\text { Editor } \\
\text { Two Art Directors } \\
\text { Art Coordinator } \\
\text { Editing Manager } \\
\text { Copy Editor } \\
\text { Two Editing Assistants }\end{array}$ \\
\hline 3 & $\begin{array}{l}\text { Staff Editor } \\
\text { Art Production Assistant } \\
\text { Editing Supervisor } \\
\text { Second Editing Assistant }\end{array}$ & $\begin{array}{l}\text { Editor in Chief } \\
\text { Staff Editor } \\
\text { Art Director } \\
\text { Art Production Supervisor } \\
\text { Editing Manager } \\
\text { Senior Editing Assistant } \\
\text { Editing Assistant }\end{array}$ \\
\hline 4 & $\begin{array}{l}\text { Senior Editor } \\
\text { Editor } \\
\text { Designer } \\
\text { Editing Supervisor } \\
\text { Production Supervisor } \\
\text { Pronunciation Editor }\end{array}$ & $\begin{array}{l}\text { Editor in Chief } \\
\text { Two Editors } \\
\text { Editorial Administrator } \\
\text { Art Director } \\
\text { Editing Manager }\end{array}$ \\
\hline 5 & $\begin{array}{l}\text { Editorial Assistant } \\
\text { Art Director } \\
\text { Assistant Art Director } \\
\text { Senior Editing Supervisor } \\
\text { Editing Supervisor } \\
\text { Senior Production Supervisor }\end{array}$ & $\begin{array}{l}\text { Editor in Chief } \\
\text { Senior Editor } \\
\text { Two Editors } \\
\text { Editorial Administrator } \\
\text { Editing Manager } \\
\text { Pronunciation Editor }\end{array}$ \\
\hline
\end{tabular}




\begin{tabular}{|l|l|l|}
\hline 6 & Publisher - Science & \\
& Managing Editor & Senior Staff Editor \\
& Two Staff Editors & Editing Manager \\
Digital Content Manager & Senior Editing Supervisor \\
& Editorial Assistant & Art Director \\
& Vice President - Editing, Design, and Production \\
& Production Manager & Assistant Art Director \\
& Senior Production Supervisor & \\
\hline
\end{tabular}

34 More information is added to the first edition (production cycle 2), which leads to the second edition (X2), and production cycle 2 is thus completed. The second edition contained 337 new entries. Additionally, some articles from the first edition were revised for the second edition. Table 2 lists the different types of changes (see Edition 2 column).

Table 2. - Types of Changes in the Articles of McGraw-Hill Dictionary of Scientific and Technical Terms.

\begin{tabular}{|c|c|c|c|c|}
\hline \multirow{2}{*}{ Types of changes } & \multicolumn{4}{|c|}{ Edition } \\
\hline & 2 & 3 & 5 & 6 \\
\hline
\end{tabular}




\begin{tabular}{|c|c|c|c|c|c|}
\hline A revised definition & 30 & 6 & 12 & 14 & 15 \\
\hline Grammar corrected in the definition & 0 & 1 & 0 & 0 & 0 \\
\hline A revised definition and a revised subject field & 1 & 0 & 0 & 1 & 3 \\
\hline A revised definition and change of number & 2 & 0 & 0 & 0 & 0 \\
\hline An altered illustration & 0 & 0 & 2 & 0 & 3 \\
\hline An additional meaning instead of a separate entry & 0 & 0 & 0 & 1 & 0 \\
\hline An additional meaning in an additional subject field & 15 & 15 & 22 & 21 & 7 \\
\hline Several additional meanings in an additional subject field & 2 & 2 & 0 & 5 & 1 \\
\hline Several additional meanings in several additional subject fields & 1 & 3 & 2 & 2 & 1 \\
\hline An additional meaning in an existing subject field & 8 & 6 & 4 & 6 & 6 \\
\hline Several additional meanings in an existing subject field & 0 & 0 & 1 & 1 & 0 \\
\hline An additional name of the subject field & 1 & 0 & 0 & 1 & 0 \\
\hline Additional information in the definition & 15 & 0 & 6 & 0 & 5 \\
\hline (An) additional synonym(s) & 11 & 2 & 4 & 12 & 11 \\
\hline An additional illustration & 3 & 0 & 1 & 1 & 8 \\
\hline An additional and/or updated illustration description & 1 & 0 & 0 & 0 & 1 \\
\hline An abbreviation explained & 0 & 0 & 1 & 0 & 0 \\
\hline A definition instead of a reference to another article & 3 & 0 & 0 & 0 & 3 \\
\hline A reference to another article instead of a definition & 2 & 0 & 1 & 6 & 0 \\
\hline One definition deleted & 1 & 1 & 0 & 1 & 3 \\
\hline Part of the definition deleted & 5 & 0 & 1 & 1 & 1 \\
\hline Part of the illustration description deleted & 1 & 0 & 0 & 10 & 1 \\
\hline A reference to another article deleted & 2 & 0 & 0 & 0 & 0 \\
\hline A synonym deleted & 3 & 0 & 33 & 0 & 1 \\
\hline An illustration deleted & 14 & 4 & 7 & 19 & 8 \\
\hline Altered order of definitions & 2 & 3 & 1 & 1 & 1 \\
\hline Altered order of synonyms & 0 & 0 & 0 & 1 & 0 \\
\hline
\end{tabular}

Furthermore, during production cycle 2, the second edition of the dictionary was prepared for consumption cycle 2'. In order to make this edition commercially successful, the following topics were addressed in the front matter: the need to keep up with the changes in science and technology, the description of the revision process, the use of the latest technologies in making the dictionary, and the characteristics that make the dictionary stand out, namely, comprehensiveness and modernity. Again, the emphasis was on the progress in science and technology rather than on getting closer to a complete volume of scientific knowledge. The second edition is then sold and used by the public (consumption cycle 2'). 
Figure 4. - Production-consumption model of the second edition of McGraw-Hill Dictionary of Scientific and Technical Terms.

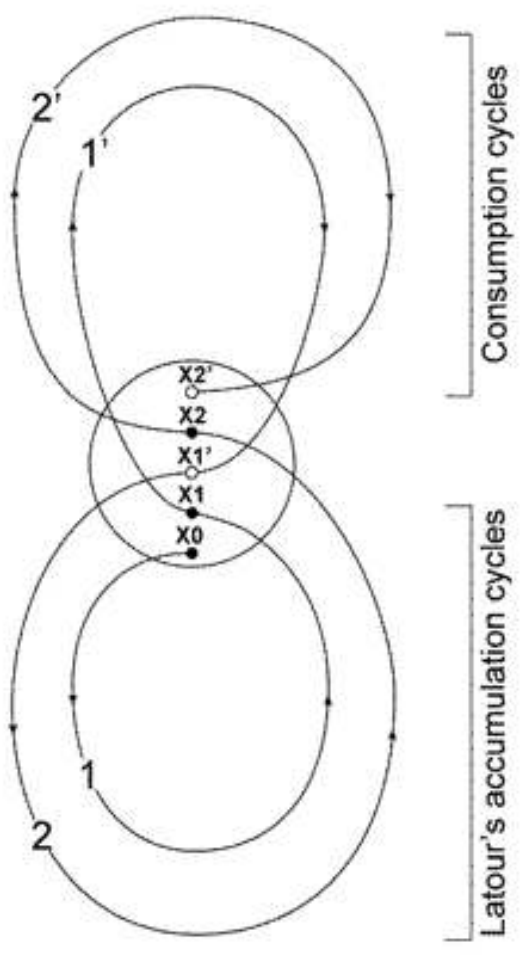

\subsection{Edition 3: 1984}

Figure 5 is the production-consumption model of the third edition of the dictionary. Again, the center includes the same publisher. Seven people on the editorial staff remained the same; new editorial staff included four people (see Table 1). All consulting and contributing editors remained the same. 
Figure 5. - Production-consumption model of the third edition of McGraw-Hill Dictionary of Scientific and Technical Terms.

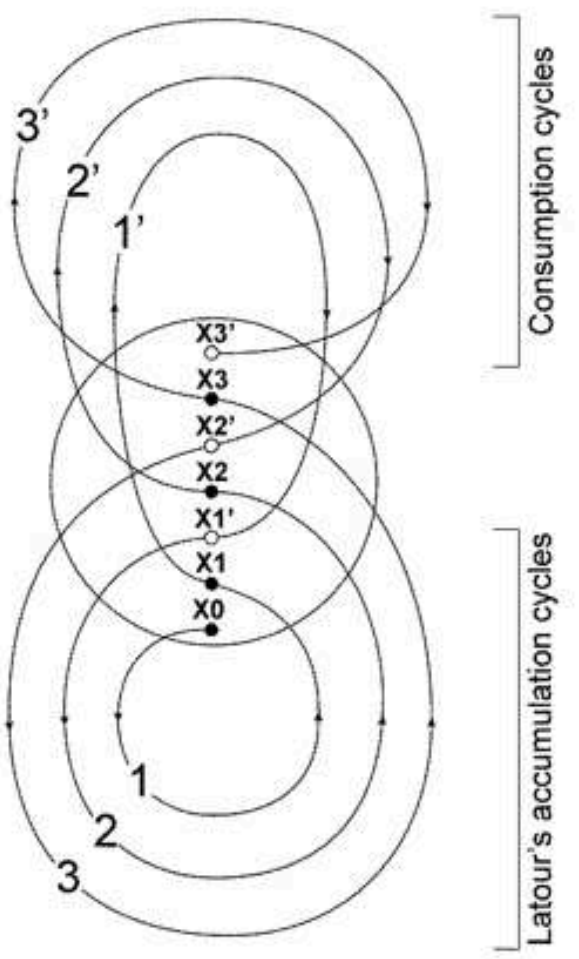

More information is added to the second edition (production cycle 3), which leads to the third edition (X3), so production cycle 3 is completed. The third edition contained 294 new entries. Also, some articles from the second edition were revised for the third edition. Table 2 contains the types of these changes (see Edition 3 column).

To ensure the commercial success of this edition, the editors discussed the following topics in the front matter: the need to keep up with the changes in science and technology, the description of the revision process, and some of the characteristics of this particular edition, namely, its comprehensiveness and status as a standard international reference. Once again, the emphasis was not on forming a complete corpus of knowledge. The third edition is then sold and used by the public (consumption cycle $3^{\prime}$ ).

\subsection{Edition 4: 1989}

The production-consumption model of the fourth edition of the dictionary would include the model of the third edition as well as production cycle 4 leading to the fourth edition $\mathrm{X} 4$ and consumption cycle 4'. The publisher (the center) remains the same. Six new people joined the editorial staff, and six remained the same (see Table 1). The Pronunciation Editor had the largest number of credentials listed, no doubt due to the fact that pronunciation was a new feature in this edition. All consulting and contributing editors stayed the same, but the credentials that followed the names (position, organization, field/role in the dictionary) were deleted due, perhaps, to the fact that, by the fourth edition, the dictionary had become a trusted authority by itself, and there was no need to reestablish the editors' authority. 
fourth edition contained 176 new entries. Some articles from the third edition were also revised for the fourth edition. Table 2 shows the type of changes made (see Edition 4 column). In order to make this edition commercially successful, the same topics as before were addressed in the front matter: the need to keep up with the changes in science and technology, a description of the revision process, and some of the characteristics of this particular edition, namely, pronunciation as an added feature and comprehensiveness of the dictionary.

\subsection{Edition 5: 1994}

41

The production-consumption model of the fifth edition of the dictionary includes the model of the fourth edition as well as production cycle 5 leading to the fifth edition X5 and consumption cycle 5'. The publisher is still McGraw-Hill Book Company. Six new people joined the editorial staff, and seven remained the same (see Table 1). Though all consulting editors remained the same, the names of contributing editors, those who wrote the definitions, were omitted.

The fifth edition contained 284 new entries. Additionally, some articles from the fourth edition were revised for the fifth edition; Table 2 shows the type of these changes (see Edition 5 column). To promote this edition's commercial success, the topics discussed in the front matter varied from the previous editions in that they dealt with the change of audience (the general reader rather than a combination of the general reader and the specialists), the increasing importance of scientific terminology, the fast pace of research, and the comprehensiveness of this edition.

\subsection{Edition 6: 2003}

Figure 6 is the production-consumption model of the sixth edition of the dictionary. Again, the institution in the center is still the same publisher. The main change in the editorial staff was the replacement of the Editor in Chief by the Publisher. Nine new people joined the editing staff, and six remained the same (see Table 1). There are two lists of consulting editors: one with the names of people who worked on previous editions (this list remained the same) and one with the names of the four people who worked on the sixth edition. As in the two previous editions, the credentials that followed the names (position, organization, field/role in the dictionary) were not present. 
Figure 6. - Production-consumption model of the sixth edition of McGraw-Hill Dictionary of Scientific and Technical Terms.

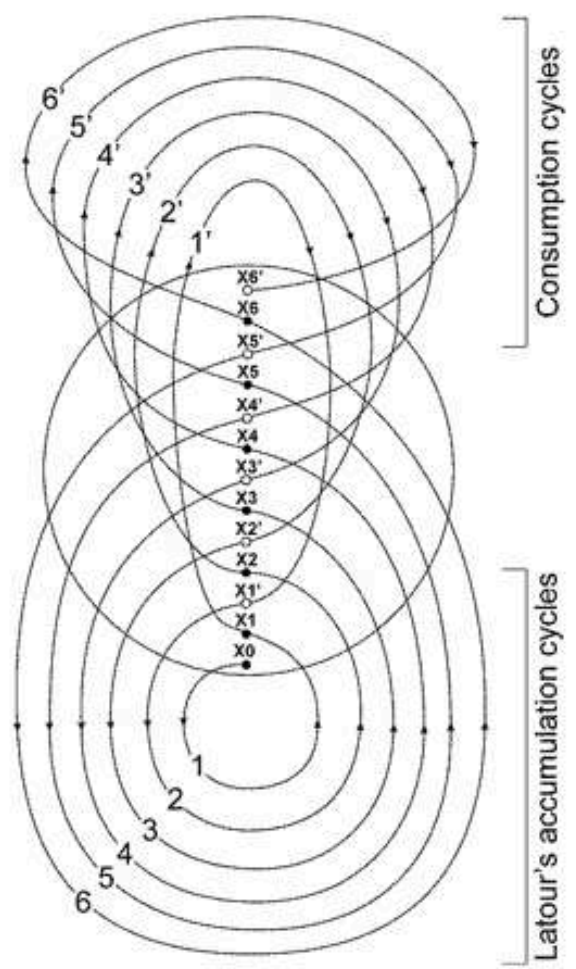

More information is added to the fifth edition (production cycle 6), which leads to the sixth edition (X6), so production cycle 6 is completed. The sixth edition contained 253 new entries. Also, some articles from the fifth edition were revised for the sixth edition. Table 2 contains the types of these changes (see Edition 6 column).

During production cycle 6, the sixth edition of the dictionary was prepared for consumption cycle 6'. For this edition, the topics discussed in the front matter concerned the need to keep up with the changes in science and technology, the description of the revision process, and some of the characteristics of this particular edition, namely, its comprehensiveness and status as a standard international reference. Again, the focus is on the development of science and technology and on the status of the dictionary, not on the necessity to form a complete corpus of knowledge. The sixth edition is then sold and used by the public (consumption cycle $6^{\prime}$ ).

\section{Conclusions}

In addition to possessing the normative power of defining terms and their subsequent use, dictionaries in general and dictionaries of science and technology in particular possess power as symbols of education and tools for creating imagined communities. In addition, dictionaries of science and technology are powerful because they participate in the scientific knowledge economy by creating knowledge and acting as products of capitalism. However, the power of dictionaries of science and technology is usually invisible because these reference works are often viewed as mundane documents. The aim of this study has been to try and make this visible: first, we propose a model that could be used to describe some of the mechanisms behind the 
power of dictionaries of science and technology; we then use this model to analyze how one of the most popular dictionaries of science and technology published in English participates in the scientific knowledge economy.

While the institution that exercises the power to make decisions about the content of the dictionary, i.e. the publisher, remained the same for all editions, changes were made to the list of the dictionary compilers-editorial staff, contributing editors, consulting editors, and library consultants-working on the different editions.

As can be seen in Figures 3 through 6, the scientific knowledge economy in which the McGraw-Hill Dictionary of Scientific and Technical Terms functioned can be described as progressive in that creating each edition became a process that involved adding new knowledge as it developed. New articles or new parts of articles are created, but no large volumes of information, such as separate volumes or supplements, are added to the dictionary. Even the different types of added information were very similar for all editions, the most popular being a revised definition, an additional meaning in an additional subject field, an additional meaning in an existing subject field, and (an) additional synonym(s) (see Table 2).

The progressive nature of this scientific knowledge economy may be explained by the cultural context: because the development of science and technology has been a major theme in the second half of the twentieth century and in the twenty-first century, adding smaller items of information connected with the new developments became widely spread. As the cultural analysis of the front matter of the dictionary shows, the theme of the development of science and technology, rather than getting closer to the complete (finite) volume of scientific knowledge, was present in all dictionary editions. Therefore, instead of targeting large volumes of new information, the dictionary compilers focused on adding smaller items of information connected with the developments of science and technology.

By modifying one of the accepted models used in cultural studies (Latour's model of knowledge accumulation) and combining methods used in lexicography and cultural studies, this study introduces a new methodology for studying the mechanisms behind the power of scientific and technical communication artifacts. Future research may include considering a wider variety of dictionaries of science and technology in terms of the subject fields and languages in a larger number of contexts, as well as exploring in greater detail the changes taking place in various elements of the proposed model, the center, the accumulation cycles, and the production cycles. More research on how dictionaries of science and technology function in the scientific knowledge economy is needed because such studies contribute to our general understanding of how dictionaries are instrumental in the creation of knowledge in our society. 


\section{BIBLIOGRAPHY}

ANDERSON Benedict Richard O'Gorman (2006), Imagined Communities: Reflections on the Origin and Spread of Nationalism, New York: Verso.

BÉJoINT Henri (1994), Tradition and Innovation in Modern English Dictionaries, New York: Oxford

University Press Inc.

CUBILLo Mari Carmen Campoy (2002), "Dictionary Use and Dictionary Needs of ESP Students:

An Experimental Approach", International Journal of Lexicography, 15, 206-28.

FABer Pamela, ARAúz Pilar León, PRieto Velasco Juan Antonio \& ReImerinK Arianne (2006), “Linking Images and Words: The Description of Specialized Concepts", International Journal of Lexicography, $20,39-65$.

FRAWLEY William (1988), “New Forms of Specialized Dictionaries”, International Journal of Lexicography, 1, 189-213.

HARRIS Roy (1982), “The History Men”, Times Literary Supplement, 3 Sep., 935-6.

ILSON Robert F. (2003), "Lexicographic Archaeology: Comparing Dictionaries of the Same Family", R. Hartmann (ed.), Lexicography: Critical Concepts (vol. 2), London and New York: Routledge, 76-84.

JACKSON Howard (2002), Lexicography: An Introduction, New York: Routledge.

KARPOVA Olga (2004), Lexicographical Portraits of Dictionaries of Modern English, Ivanovo, Ivanovo, Russia: Ivanovo State University.

KARPOVA Olga (2010), English Lexicography, Moscow, Russia: Academy.

KeRnAN Alvin (1987), Printing Technology, Letters, and Samuel Johnson, Princeton, NJ: Princeton University Press.

LANDAU Sidney I. (1984), Dictionaries: The Art and Craft of Lexicography, New York: The Scribner Press.

LANDAU Sidney I. (2001), Dictionaries: The Art and Craft of Lexicography, Cambridge: Cambridge University Press.

LATouR Bruno (1987), Science in Action: How to Follow Scientists and Engineers through Society, Cambridge, Mass.: Harvard University Press.

LAYTON David (1965), "Diction and Dictionaries in the Diffusion of Scientific Knowledge: An Aspect of the History of the Popularization of Science in Great Britain", The British Journal for the History of Science, 2, 221-34.

LEITCH Vincent B. (1992), Cultural Criticism, Literary Theory, Poststructuralism, New York: Columbia University Press.

LoNGo Bernadette (2000), Spurious Coin: A History of Science, Management, and Technical Writing, Albany, NY: State University of New York Press.

McGraw-Hill Dictionary of Scientific and Technical Terms (1974), New York: McGraw-Hill Book Company.

McGraw-Hill Dictionary of Scientific and Technical Terms (2nd ed.) (1978), New York: McGraw-Hill Book Company. 
McGraw-Hill Dictionary of Scientific and Technical Terms (3rd ed.) (1984), New York: McGraw-Hill Book Company.

McGraw-Hill Dictionary of Scientific and Technical Terms (4th ed.) (1989), New York: McGraw-Hill Book Company.

McGraw-Hill Dictionary of Scientific and Technical Terms (5th ed.) (1994), New York: McGraw-Hill Book Company.

McGraw-Hill Dictionary of Scientific and Technical Terms (6th ed.) (2003), New York: McGraw-Hill Book Company.

NoRMAN Guy (2002), "Description and Prescription in Dictionaries of Scientific Terms", International Journal of Lexicography, 15(4), 259-76.

OPITz Kurt (1983), “Special-Purpose Lexicography: Dictionaries for Technical Use”, R. Hartmann (ed.), Lexicography: Principles and Practice, London: Academic Press, 163-80.

Pedersen Jette (1995), “The Identification and Selection of Collocations in Technical Dictionaries”, Lexicographica, 11, 60-73.

YEO Richard (2001), Encyclopedic Visions: Scientific Dictionaries and Enlightenment Culture, Cambridge: Cambridge University Press.

\section{ABSTRACTS}

Dictionaries of science and technology possess power because they contribute to the scientific knowledge economy by creating knowledge and acting as products of capitalism. However, the power of dictionaries of science and technology is usually invisible because these reference works are often viewed as common, everyday documents. In this study, we undertake to discuss this power. First, we propose a model of production-consumption cycles that could be used to describe some of the mechanisms behind the power of dictionaries of science and technology. Second, we use this model to analyze how one of the most popular dictionaries of science and technology published in English, McGraw-Hill Dictionary of Scientific and Technical Terms, contributes to the scientific knowledge economy.

Le pouvoir des dictionnaires de sciences et technologies repose sur le fait que ces derniers participent à l'économie de la connaissance scientifique, en générant du savoir et en tant que produits du capitalisme. Cependant, le pouvoir de ces dictionnaires est la plupart du temps invisible, car ces ouvrages de référence sont souvent perçus comme des documents relevant du quotidien. Cet article propose d'analyser cette forme de pouvoir. Dans un premier temps, nous présentons un modèle des cycles de production et de consommation qui pourrait servir à décrire les mécanismes qui sous-tendent le pouvoir des dictionnaires de sciences et technologies. Nous proposons, ensuite, d'utiliser ce modèle pour illustrer comment l'un de ces dictionnaires en langue anglaise les plus populaires, le McGraw-Hill Dictionary of Scientific and Technical Terms, contribue à l'économie de la connaissance scientifique. 


\section{INDEX}

Mots-clés: dictionnaires des sciences et de la technologie, économie fondée sur la connaissance scientifique, lexicographie, études culturelles

Keywords: dictionaries of science and technology, scientific knowledge economy, lexicography, cultural studies

\section{AUTHOR}

\section{OLGA MENAGARISHVILI}

Metropolitan State University, St. Paul, Minnesota, USA.

Olga Menagarishvili is Assistant Professor in the Depart. of Technical Communication and Interaction Design at Metropolitan State University, St. Paul, Minnesota, USA.

Her research interests include scientific and technical communication, technical communication pedagogy, online and blended learning pedagogy, multimodality, rhetoric, and lexicography. Her two most recent publications are "Student Attitudes About Teamwork in Face-to-Face and Blended Technical Communication Classes" (with R. E. Burnett \& A. Frazee), in Blended Learning: A Guide for Researchers and Practitioners, Cambridge, MA: MIT Press, 2019, and "Energy Communication in International Contexts" (with C. Landais, N. A. Peach \& A. Armstrong), in Proceedings of 2019 IEEE International Professional Communication Conference (ProComm), Aachen, Germany, 2019.

olga.menagarishvili@metrostate.edu 